International Journal of Current Micro6iology and Applied Sciences

ISSN: 2319-7706 Volume 8 Number 10 (2019)

Journal homepage: http://www.ijcmas.com

Original Research Article

https://doi.org/10.20546/ijcmas.2019.810.251

\title{
Effect of the Best Dose of N, P and K Fertilizers for Better Growth and Yield of Cauliflower (Brasica oleracea Var. botrytiss L.)
}

\author{
Gangesh Pandey, K. K. Mishra*, Aneeta Yadav and Abhishek Tiwari \\ Department of Horticulture, Faculty of Agricultural Sciences and Allied Industries, \\ Rama University, Kanpur(U.P.), India \\ *Corresponding author
}

Keywords

Cauliflower,

Snowball, Fertilizer,

Growth and Yield

Article Info

Accepted:

15 September 2019

Available Online:

10 October 2019

\section{A B S T R A C T}

The area lies under the upper Gangetic plains region of Uttar Pradesh at an elevation of $126 \mathrm{~m}$. above mean sea level. The investigation revealed that is very responsive to the different treatment combination that is $\mathrm{T}_{1}$ control, $\mathrm{T}_{2}$ NPK (30+20+10 kg/ha.), $T_{3}$ NPK (50+40+30 kg/ha.) $\mathrm{T}_{4}$ NPK $(75+50+40$ $\mathrm{kg} / \mathrm{ha}$.), $\mathrm{T}_{5} \mathrm{NPK}\left(100+60+50 \mathrm{~kg} / \mathrm{ha}\right.$.) and $\mathrm{T}_{6} \mathrm{NPK}(120+80+60 \mathrm{~kg} / \mathrm{ha}$.). All the treatment improve the vegetative growth and yield quality of cauliflower but $\mathrm{T}_{6}\{\mathrm{NPK}(120+80+60) \mathrm{kg} / \mathrm{ha}$. $\}$ gave the best results in terms of increasing size of curd, weight of curd, diameter of stem, plant height and yield followed by $\mathrm{T}_{5}\{\mathrm{NPK}(100+60+50) \mathrm{kg} / \mathrm{ha}$. $\}, \mathrm{T}_{4}\{\mathrm{NPK}$ $(75+50+40) \mathrm{kg} / \mathrm{ha}$. $\}$ and minimum recorded in control. Hence treatment $\mathrm{T}_{6}$ $\{\mathrm{NPK}(120+80+60) \mathrm{kg} / \mathrm{ha}$. $\}$ for curd size, economic point of view and higher yield can be recommend for commercial cultivation of cauliflower production.

\section{Introduction}

Cauliflower (Brassica oleracea Var. Botrytis L.) is one of the important members of the group 'Cole crop' vegetables. It is belonging to Cruciferae family. The origin place of cauliflower is Mediterranean region. It is also one of the most important popular and widely cultivated all over India and abroad for its nutrative value, high productivity and wider adaptability under different ecological condition. In India Uttarakhand, Uttar Pradesh, Himachal Pradesh, Haryana, Rajasthan, Bihar, Gujarat, Maharashtra, Odisha and Karnataka is produce large quantities of cauliflower.

It is also commonly grown in northern Himalayas and in Nilgiri hills in south. In its vegetative growth period, it may stand temperature as low as $-10^{\circ} \mathrm{C}$ and as high as $40^{\circ} \mathrm{C}$ for a few days. Morphologically, the 
curd of cauliflower is made up of numerous divided hypertropic branches, which terminate the main stem of the plant. It is good source of vitamin-A, vitamin-C, riboflavin, thiamin, nicotinic acid, calcium, phosphorus, potassium, moisture, carbohydrates, protein, fat, fiber and iron (Fageria et al., 2012). Cauliflower is a deep rooted crop.

It remove a large amount of nitrogen, phosphorus and potash from the soil, wherever, it is grown and if this large amount is not supplied through the application of fertilizers, the soil on which this crop is grown is bound to deteriorate gradually and would produce very poor yields.

Intensive cultivation of vegetables needs additional supply of plant nutrients for increased production of vegetables as well as their seeds. Among the inorganic fertilizers, nitrogen encourages the development of leaves and shoots and imports a deep green colour to stem.

It is a constituent of both chlorophyll and protoplasm and is vitally essential to energy formation within the plant and development of its cellular contents.

Phosphorus (P) is one of the most essential plant nutrients that influence the growth and productivity of cauliflower.

Potassium is also equally important as structural components of all constituent and metabolically active compounds.

They hasten the maturity of crops, promote shoot developments, improve the productivity, quality of crop and increase the resistance against the disease. It also regulates water conduction within the plant cell and water loss from the plant by maintaining the balance between anabolism, respiration and transpiration.

\section{Materials and Methods}

The present investigation entitled," Effect of $\mathrm{N}, \mathrm{P}$ and $\mathrm{K}$ fertilizers on the growth and yield of cauliflower (Brassica oleracea Var. botrytis L.) cv. Snowball" was carried out under the agro-climatic and soil conditions of Kanpur (U.P.) region during the rabi season, 2018- 19. The techniques and material used are described in the following heads:

\section{Experimental Site}

The experiment was laid out in the experimental area of Horticulture Section, Rama University Mandhana Kanpur (U.P.). The field was having good topography with adequate irrigation facilities.

\section{Layout of experiment}

The experiment was conducted in randomized block design (R.B.D.) with 6 treatments replicated fourth in 24 plots.

\section{Detail of the experiment (Table 1)}

\begin{tabular}{|c|c|}
\hline Experiment Design & $\begin{array}{l}\text { RBD } \\
\text { (Randomized } \\
\text { Block } \\
\text { Design) }\end{array}$ \\
\hline Number of treatment & 6 \\
\hline Number of replication & 4 \\
\hline Total number of plot & 24 \\
\hline Plot border & $0.25 \mathrm{~m}$ \\
\hline Distance, Row x Row & $50 \mathrm{~cm}$ \\
\hline Plant x Plant & $40 \mathrm{~cm}$ \\
\hline Net plot size & $2.4 \mathrm{~m} \times 2.0 \mathrm{~m}$ \\
\hline Replication border & $0.5 \mathrm{~m}$ \\
\hline Irrigation channel & $1.0 \mathrm{~m}$ \\
\hline Variety & Snowball \\
\hline
\end{tabular}

\section{Detail of treatment}

There were six applications of mixture of $\mathrm{N}, \mathrm{P}$ and $\mathrm{K}$ fertilizer in experiment as following. 


\begin{tabular}{|l|l|}
\hline $\mathrm{T}_{1}$ & Control (No NPK) \\
\hline $\mathrm{T}_{2}$ & $(30+20+10) \mathrm{kg} / \mathrm{ha}$ \\
\hline $\mathrm{T}_{3}$ & $(50+40+30) \mathrm{kg} / \mathrm{ha}$ \\
\hline $\mathrm{T}_{4}$ & $(75+50+40) \mathrm{kg} / \mathrm{ha}$ \\
\hline $\mathrm{T}_{5}$ & $(100+60+50) \mathrm{kg} / \mathrm{ha}$ \\
\hline $\mathrm{T}_{6}$ & $(120+80+60) \mathrm{kg} / \mathrm{ha}$ \\
\hline
\end{tabular}

\section{Observations recorded}

Observation on growth characters which ultimately influenced the yield i.e. height of plants at harvesting stage, diameter of stem, and number of leaves per plants were recorded at regular intervals of 20 days commencing from 20 days after transplanting.

Observations regarding the curd character like size of curd, weight of curd per plant, yield per hectare were recorded at the time of harvesting.

\section{Results and Discussion}

The result obtained during the course of present experiment "Effect of mixture of $\mathrm{N}, \mathrm{P}$ and $\mathrm{K}$ fertilizers on the growth and yield of cauliflower (Brassica oleracea Var. botrytis L.) cv. Snowball" has been presented under suitable heads. Observations were recorded during the growth phase at interval of 20 days commencing from 20 days after transplanting, while, the last observation was recorded at 60 days after planting and on yield attributing characters per plant at the time of picking of cauliflower curd. Measurement of the height of plant was started 20 days after transplanting with an interval of 20 days. The height of the plant as affected by different treatments is given in Table 2. At all the growth stages, maximum plant height was recorded under the mixture application of $\mathrm{T}_{6}(120+80+60) \mathrm{kg} / \mathrm{ha}$ $\mathrm{N}, \mathrm{P}, \mathrm{K}$, followed by $\mathrm{T}_{5}(100+60+50) \mathrm{kg} / \mathrm{ha}$ $\mathrm{N}, \mathrm{P}, \mathrm{K}$ and minimum height was recorded under $\mathrm{T}_{2}(30+20+10) \mathrm{kg} / \mathrm{ha}$ NPK fallowed by $\mathrm{T}_{1}$ (No N,P,K) (Fig. 1). The maximum stem diameter was produced under the mixtures of NPK fertilizers $T_{6}(120+80+60) \mathrm{kg} / \mathrm{ha}$ NPK at all the stages, followed by $\mathrm{T}_{5}(100+60+50)$ $\mathrm{kg} / \mathrm{ha} \mathrm{N}, \mathrm{P}$ and $\mathrm{K}$ (Fig. 2). While the minimum stem diameter was recorded under the mixtures of NPK fertilizers T2 $(30+20+10)$ $\mathrm{kg} / \mathrm{ha}$ NPK fallowed by $\mathrm{T}_{1}$ control (No NPK). It is evident from the Table 3. The number of leaves was recorded at 20 days interval commencing from 20 days after planting and the data of all the subsequent growth stages are presented in Figure 3. Maximum and significantly higher number of leaves/plant was observed under mixtures of NPK fertilizers $\mathrm{T}_{6} \quad(120+800+60) \mathrm{kg} / \mathrm{ha} \quad \mathrm{NPK}$, followed by $\mathrm{T}_{5}(100+60+50) \mathrm{kg} / \mathrm{ha}$ NPK at all the growth stages (Table 4).

While, minimum No. of leaf per plant were observed under $\mathrm{T}_{2}(30+20+10) \mathrm{kg} / \mathrm{ha}$ NPK fallowed by $\mathrm{T}_{1}$ (No NPK). The average size of cauliflower curd was recorded at the time of picking shown in Figure 4. The mixture of NPK fertilizers application $\mathrm{T}_{6}(120+80+60)$ $\mathrm{kg} / \mathrm{ha}$ NPK gave maximum size of cauliflower curd in comparison to the other mixture of fertilizers. It was followed by mixture of fertilizers $\mathrm{T}_{5}(100+60+50) \mathrm{kg} / \mathrm{ha}$ NPK. While, minimum size of curd were observed in $\mathrm{T}_{3}$ $(50+40+30) \mathrm{kg} / \mathrm{ha}$ NPK fallowed by $\mathrm{T}_{2}$ $(30+20+10) \mathrm{kg} / \mathrm{ha}$ NPK. Treatment $\mathrm{T}_{6}$ $(120+80+60) \mathrm{kg} / \mathrm{ha}$ NPK produced cauliflower curds of maximum length $(21 \mathrm{~cm})$ followed by mixture of NPK fertilizer application $\mathrm{T}_{5}$ $(100+60+50) \mathrm{kg} / \mathrm{ha}$ NPK produced cauliflower curd. Maximum length $(19.85 \mathrm{~cm})$ found $\mathrm{T}_{2}$ $(30+20+10) \mathrm{kg} / \mathrm{ha}$ NPK and minimum length of cauliflower curd $(11.70 \mathrm{~cm})$ in $T_{1}$ control. Maximum width of cauliflower curds (17.30 $\mathrm{cm})$ found in $\mathrm{T}_{6}(120+80+60) \mathrm{kg} / \mathrm{ha} \mathrm{NPK}$ followed by $\mathrm{T}_{5}(100+60+50) \mathrm{kg} / \mathrm{ha}$ NPK while minimum width of cauliflower curd $T_{1}$ (Control No NPK). 
Table.1 Details of operations performed in the experiments

\begin{tabular}{|c|l|c|}
\hline S. No. & Operation & Date \\
\hline $\mathbf{1 .}$ & First ploughing by cultivator & $23-11-2018$ \\
\hline $\mathbf{2 .}$ & Second ploughing by rotavator & $24-11-2018$ \\
\hline $\mathbf{3 .}$ & Basal dose NPK & $24-11-2018$ \\
\hline $\mathbf{4 .}$ & Transplanting of seedling & $25-11-2018$ \\
\hline $\mathbf{5 .}$ & Water by water cane & $25-11-2018$ \\
\hline $\mathbf{6 .}$ & Irrigation-I & $29-11-2018$ \\
\hline $\mathbf{7 .}$ & Gap filling & $02-12-2018$ \\
\hline $\mathbf{8 .}$ & Weeding and hoeing & $06-12-2018$ \\
\hline $\mathbf{9 .}$ & Irrigation-II & $08-12-2018$ \\
\hline $\mathbf{1 0 .}$ & First Observation & $15-12-2018$ \\
\hline $\mathbf{1 1}$. & Irrigation-III & $18-12-2018$ \\
\hline $\mathbf{1 2 .}$ & Urea I split dose & $25-12-2018$ \\
\hline $\mathbf{1 3 .}$ & Irrigation-IV & $26-12-2018$ \\
\hline $\mathbf{1 4 .}$ & Second observation & $04-01-2019$ \\
\hline $\mathbf{1 5 .}$ & Insecticide spray & $04-01-2019$ \\
\hline $\mathbf{1 6 .}$ & Irrigation-V & $06-01-2019$ \\
\hline $\mathbf{1 7 .}$ & Weeding Second & $15-01-2019$ \\
\hline $\mathbf{1 8 .}$ & Remaining dose of Urea & $16-01-2019$ \\
\hline $\mathbf{1 9}$ & Irrigation-VI & $16-01-2019$ \\
\hline $\mathbf{2 0}$ & Third observation & $24-01-2019$ \\
\hline $\mathbf{2 1 .}$ & Irrigation-VII & $26-01-2019$ \\
\hline $\mathbf{2 2 .}$ & Picking-I & $03-02-2019$ \\
\hline $\mathbf{2 3 .}$ & Irrigation-VIII & $04-02-2019$ \\
\hline $\mathbf{2 4}$. & Picking-II & $09-02-2019$ \\
\hline $\mathbf{2 5}$. & Irrigation-IX & $12-02-2019$ \\
\hline $\mathbf{2 6 .}$ & Final Picking & $16-02-2019$ \\
\hline & & \\
\hline
\end{tabular}

Table.2 Effect of different dose of N, P and K fertilizers on plant height $(\mathrm{cm})$

\begin{tabular}{|c|l|c|c|c|}
\hline \multirow{2}{*}{ Sr. No. } & Treatment & \multicolumn{3}{|c|}{ Plant Height (cm) } \\
\cline { 3 - 5 } & & 20 Days & 40 Days & 60 Days \\
\hline $\mathbf{1}$ & Control & 7.00 & 18.79 & 27.64 \\
\hline $\mathbf{2}$ & $(30+20+10) \mathrm{kg} . / \mathrm{ha} \mathrm{NPK}$ & 7.57 & 19.39 & 29.58 \\
\hline $\mathbf{3}$ & $(50+40+30) \mathrm{kg} . / \mathrm{ha} \mathrm{NPK}$ & 8.64 & 19.90 & 30.97 \\
\hline $\mathbf{4}$ & $(75+50+40) \mathrm{kg} . / \mathrm{ha} \mathrm{NPK}$ & 9.63 & 20.82 & 32.00 \\
\hline $\mathbf{5}$ & $(100+60+50+) \mathrm{kg} . / \mathrm{ha} \mathrm{NPK}$ & 10.54 & 21.95 & 32.52 \\
\hline $\mathbf{6}$ & $(120+80+60) \mathrm{kg} . / \mathrm{h}$ NPK & 11.28 & 22.72 & 33.68 \\
\hline SE $\mathbf{( m )}$ & & 0.35 & 0.09 & 0.38 \\
\hline C.D. & & 1.06 & 0.94 & 1.15 \\
\hline
\end{tabular}


Table.3 Effect of different dose of NPK fertilizer on diameter of stem $(\mathrm{cm})$

\begin{tabular}{|c|c|c|c|c|}
\hline \multirow{2}{*}{ Sr. No. } & \multirow{2}{*}{ Treatment } & \multicolumn{3}{|c|}{ Diameter of Stem (cm) } \\
\cline { 2 - 4 } & & 20 Days & 40 Days & 60Days \\
\hline $\mathbf{1}$ & Control & 0.36 & 1.14 & 1.48 \\
\hline $\mathbf{2}$ & $(30+20+10) \mathrm{kg} . / \mathrm{ha} \mathrm{NPK}$ & 0.42 & 1.25 & 1.55 \\
\hline $\mathbf{3}$ & $(50+40+30) \mathrm{kg} . / \mathrm{ha} \mathrm{NPK}$ & 0.43 & 1.40 & 1.68 \\
\hline $\mathbf{4}$ & $(75+50+40) \mathrm{kg} . / \mathrm{ha} \mathrm{NPK}$ & 0.49 & 1.52 & 1.80 \\
\hline $\mathbf{5}$ & $(100+60+50+) \mathrm{kg} . / \mathrm{ha} \mathrm{NPK}$ & 0.53 & 1.64 & 1.91 \\
\hline $\mathbf{6}$ & $(120+80+60) \mathrm{kg} . / \mathrm{ha} \mathrm{NPK}$ & 0.57 & 1.70 & 1.93 \\
\hline SE $\mathbf{( m )}$ & & 0.01 & 0.01 & 0.03 \\
\hline C.D. & & 0.03 & 0.05 & 0.10 \\
\hline
\end{tabular}

Table.4 Effect of N, P and K fertilizer at number of leaf per plant

\begin{tabular}{|c|c|c|c|c|}
\hline \multirow{2}{*}{ Sr. No. } & Treatment & \multicolumn{3}{|c|}{ No. Of Leaf } \\
\cline { 3 - 4 } & & 20 Days & 40 Days & 60Days \\
\hline $\mathbf{1}$ & Control & 3.75 & 9.75 & 12.22 \\
\hline $\mathbf{2}$ & $(30+20+10) \mathrm{kg} . / \mathrm{ha}$ NPK & 5.12 & 11.00 & 14.00 \\
\hline $\mathbf{3}$ & $(50+40+30) \mathrm{kg} . / \mathrm{ha}$ NPK & 6.37 & 13.57 & 15.60 \\
\hline $\mathbf{4}$ & $(75+50+40) \mathrm{kg} . / \mathrm{ha} \mathrm{NPK}$ & 7.37 & 14.87 & 16.87 \\
\hline $\mathbf{5}$ & $(100+60+50+) \mathrm{kg} . / \mathrm{ha} \mathrm{NPK}$ & 8.75 & 16.87 & 17.37 \\
\hline $\mathbf{6}$ & $(120+80+60) \mathrm{kg} . / \mathrm{ha} \mathrm{NPK}$ & 9.87 & 19.75 & 21.12 \\
\hline SE $\mathbf{( m )}$ & & 0.18 & 0.34 & 0.44 \\
\hline C.D. & & 0.55 & 1.04 & 1.34 \\
\hline
\end{tabular}

Table.5 Effect of mixture of different dose of NPK fertilizer on size of curd $(\mathrm{cm})$

\begin{tabular}{|c|c|c|c|}
\hline \multirow{2}{*}{ Sr. No. } & Treatment & \multicolumn{2}{|c|}{ Size Of Curd (cm) } \\
\hline & & Length & Width \\
\hline $\mathbf{1}$ & Control & 11.70 & 9.05 \\
\hline $\mathbf{2}$ & $(30+20+10) \mathrm{kg} . / \mathrm{ha} \mathrm{NPK}$ & 14.65 & 11.75 \\
\hline $\mathbf{3}$ & $(50+40+30) \mathrm{kg} . / \mathrm{ha} \mathrm{NPK}$ & 16.60 & 13.55 \\
\hline $\mathbf{4}$ & $(75+50+40) \mathrm{kg} . / \mathrm{ha} \mathrm{NPK}$ & 18.25 & 14.70 \\
\hline $\mathbf{5}$ & $(100+60+50+) \mathrm{kg} . / \mathrm{ha} \mathrm{NPK}$ & 19.85 & 16.00 \\
\hline $\mathbf{6}$ & $(120+80+60) \mathrm{kg} . / \mathrm{ha} \mathrm{NPK}$ & 21.00 & 17.30 \\
\hline SE $\mathbf{( m )}$ & & 0.38 & 0.25 \\
\hline C.D. at & & 1.15 & 0.75 \\
\hline $\mathbf{5} \%$ & & & \\
\hline
\end{tabular}


Table.6 Effect of different dose of NPK fertilizer on weight of curd (g)

\begin{tabular}{|c|c|c|}
\hline Sr. No. & Treatment & Weight of Curd at Harvesting Stage (cm) \\
\hline $\mathbf{1}$ & Control & 198.30 \\
\hline $\mathbf{2}$ & $(30+20+10) \mathrm{kg} . / \mathrm{ha} \mathrm{NPK}$ & 241.21 \\
\hline $\mathbf{3}$ & $(50+40+30) \mathrm{kg} . / \mathrm{ha} \mathrm{NPK}$ & 289.93 \\
\hline $\mathbf{4}$ & $(75+50+40) \mathrm{kg} . / \mathrm{ha} \mathrm{NPK}$ & 336.25 \\
\hline $\mathbf{5}$ & $(100+60+50+) \mathrm{kg} . / \mathrm{ha} \mathrm{NPK}$ & 415.04 \\
\hline $\mathbf{6}$ & $(120+80+60) \mathrm{kg} . / \mathrm{ha} \mathrm{NPK}$ & 529.68 \\
\hline SE $\pm(\mathbf{m})$ & & 2.63 \\
\hline C.D. & & 7.94 \\
\hline
\end{tabular}

Table.7 Effect of different dose of NPK fertilizer on yield of cauliflower/ha

\begin{tabular}{|c|c|c|}
\hline Sr. No. & Treatment & Yield of Curd (q/ha) \\
\hline $\mathbf{1}$ & Control & 79.70 \\
\hline $\mathbf{2}$ & $(30+20+10) \mathrm{kg} . / \mathrm{ha} \mathrm{NPK}$ & 99.75 \\
\hline $\mathbf{3}$ & $(50+40+30) \mathrm{kg} . / \mathrm{ha} \mathrm{NPK}$ & 120.12 \\
\hline $\mathbf{4}$ & $(75+50+40) \mathrm{kg} . / \mathrm{h}$ NPK & 144.87 \\
\hline $\mathbf{5}$ & $(100+60+50+) \mathrm{kg} . / \mathrm{ha} \mathrm{NPK}$ & 168.12 \\
\hline $\mathbf{6}$ & $(120+80+60) \mathrm{kg} . / \mathrm{ha} \mathrm{NPK}$ & 206.57 \\
\hline SE $\pm(\mathbf{m})$ & & 3.33 \\
\hline C.D. & & 10.04 \\
\hline
\end{tabular}

Fig.1 Effect of different dose of N, P and K fertilizers on plant height $(\mathrm{cm})$

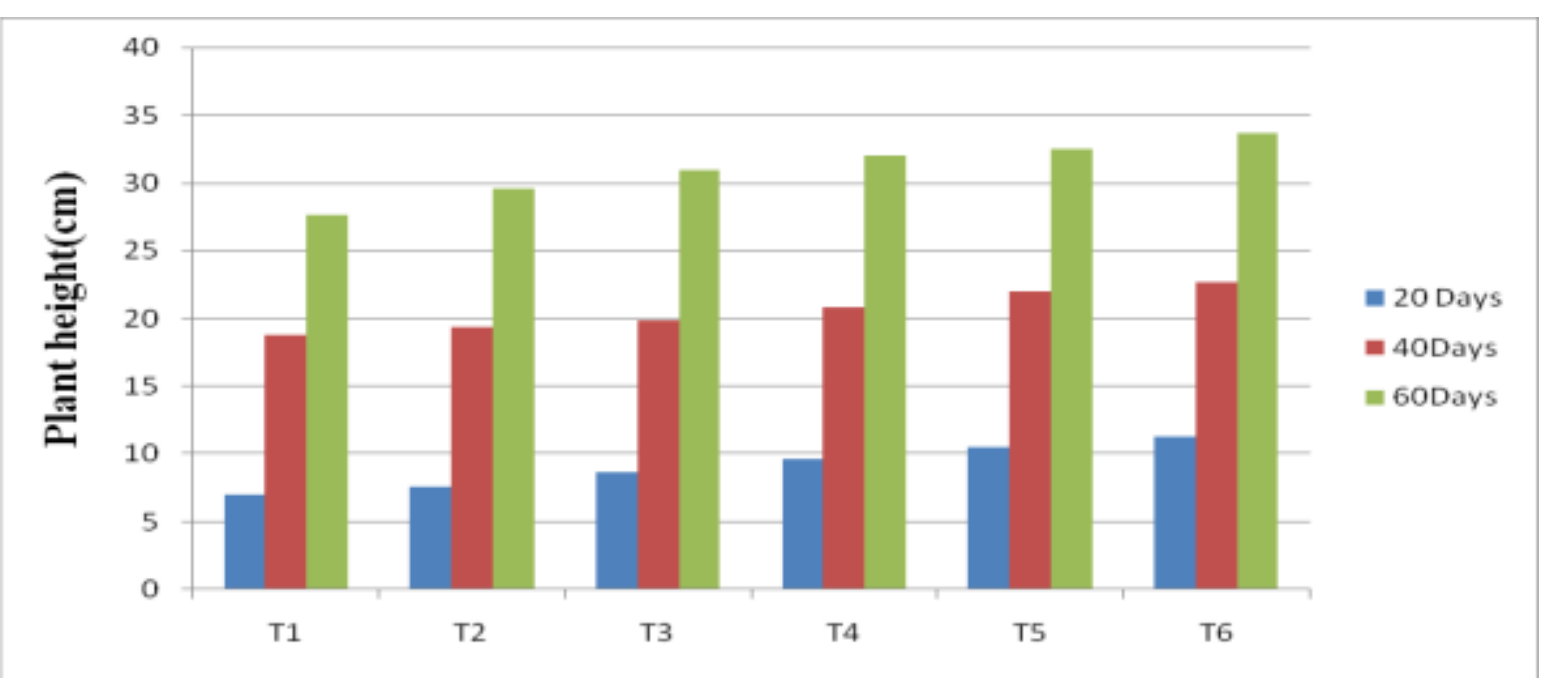


Fig.2 Effect of N, P and K fertilizer on diameter of stem/plant (cm)

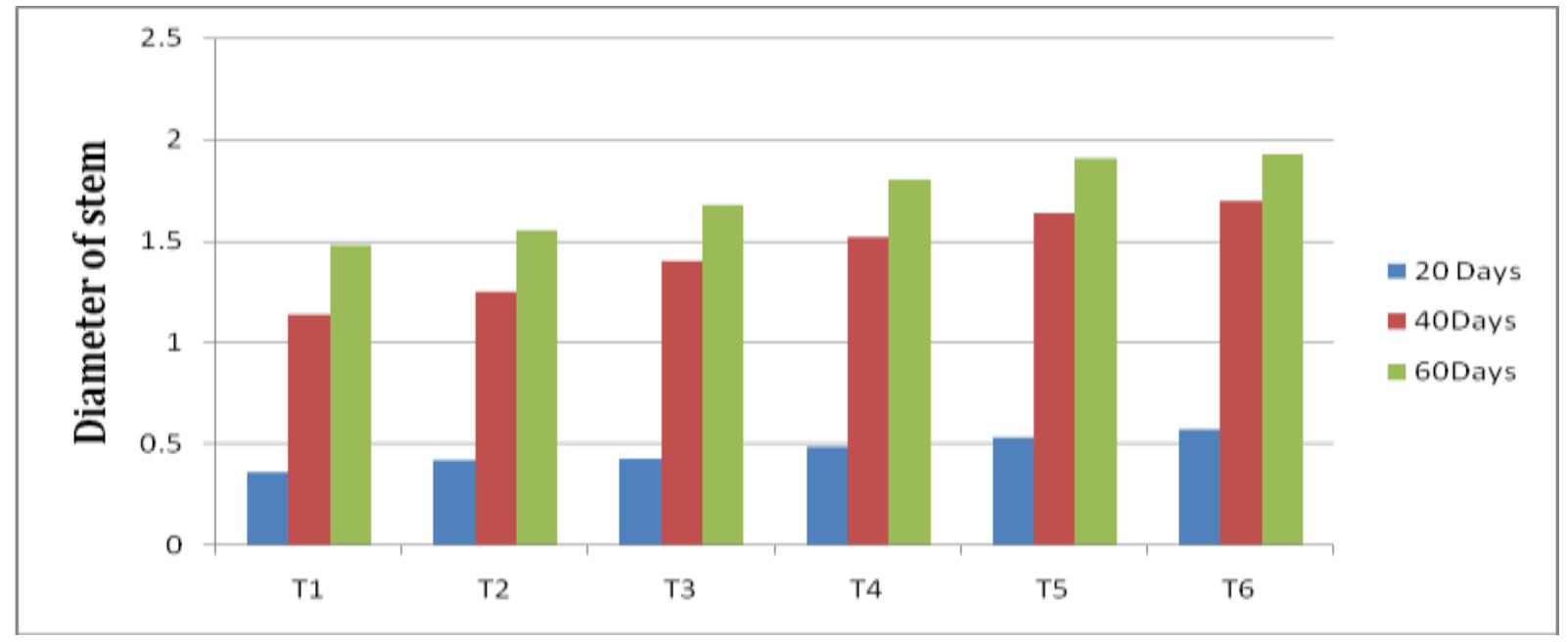

Fig.3 Effect of N, P and K fertilizer at number of leaf per plant

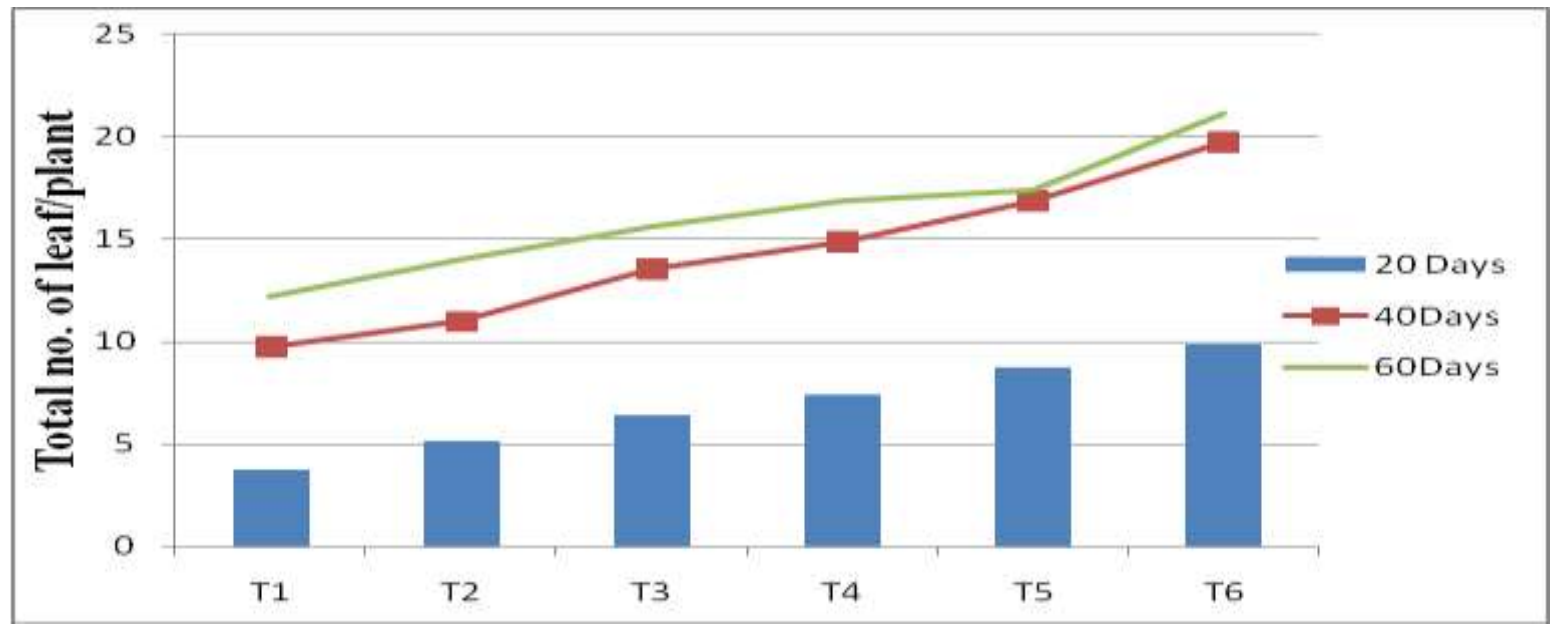

Fig.4 Effect of N, P and K fertilizer on size of curd

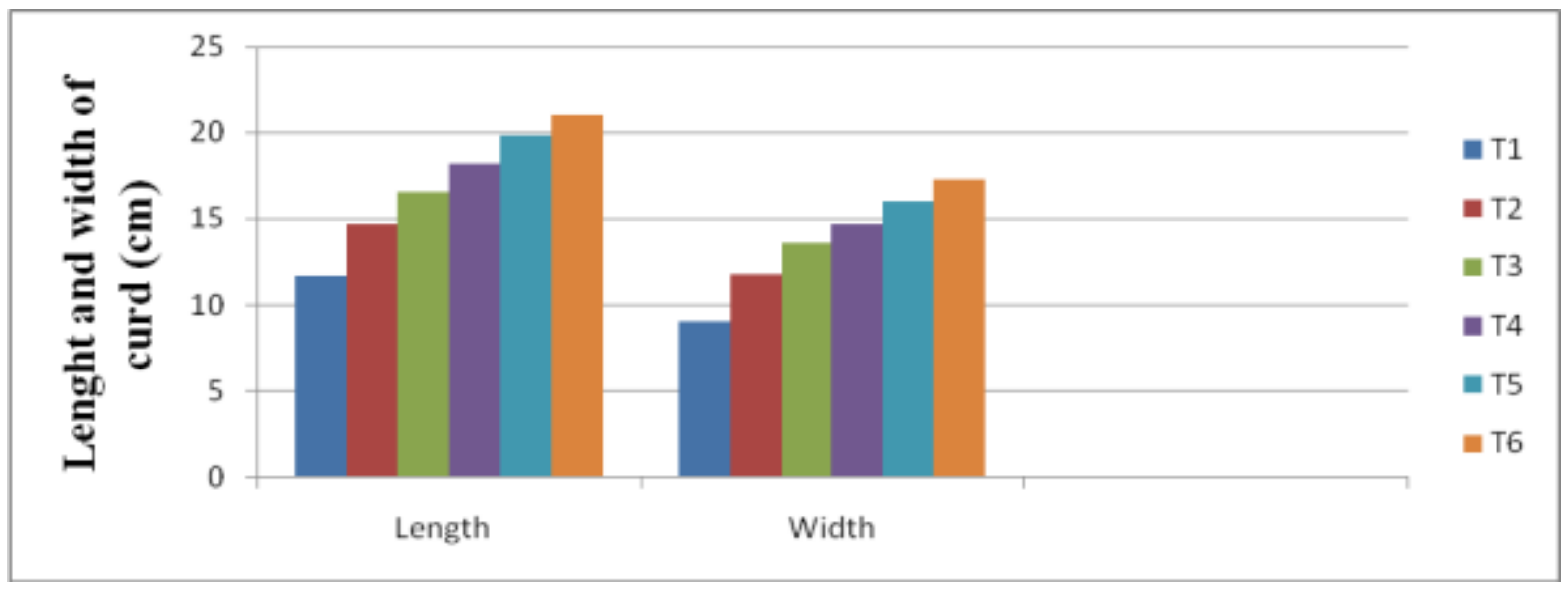


Fig.5 Effect of different dose of NPK fertilizer on weight of curd (g)

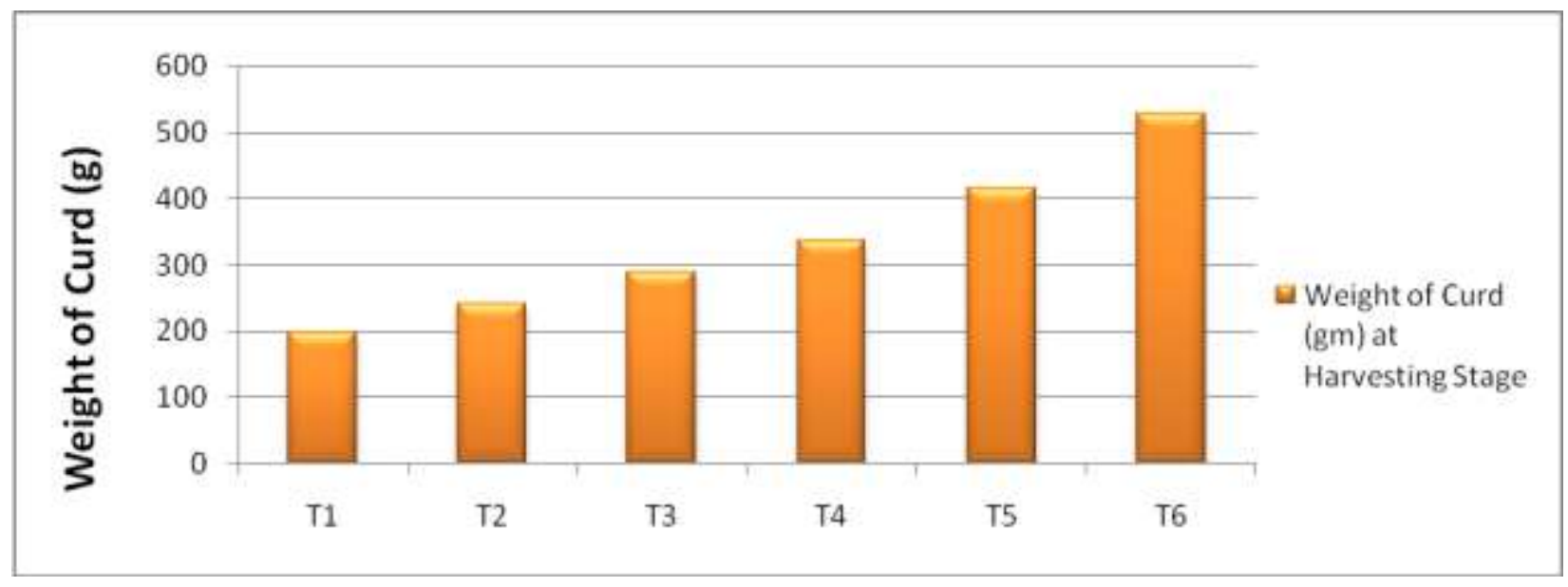

Fig.6 Effect of different dose of NPK fertilizer on yield of cauliflower/ha

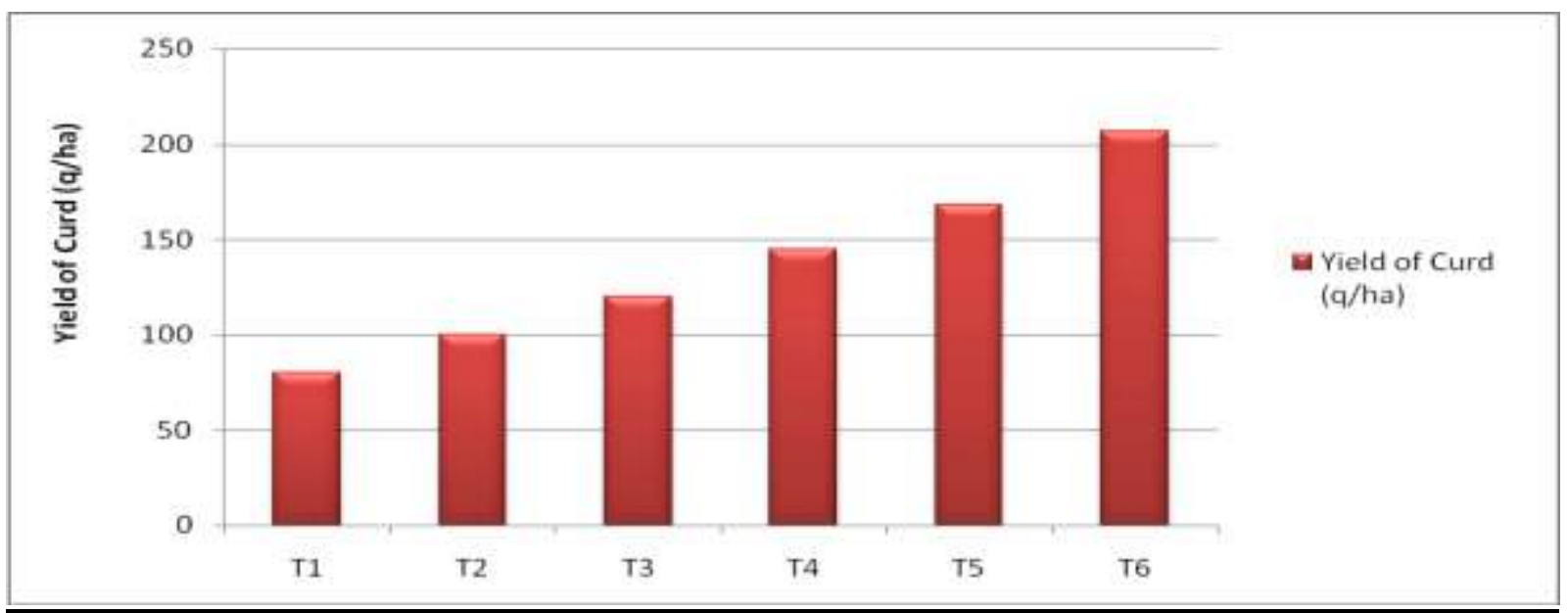

The yield/plot under different treatments were recorded at the time of subsequent picking and converted into yield $\mathrm{q} / \mathrm{ha}$ and presented in Table 7.

The average weight of curd produced by different treatments is presented in Table 6 and shown graphically in Figure 5. The mixture of NPK fertilizers $\mathrm{T}_{6}(120+80+60)$ $\mathrm{kg} / \mathrm{ha}$ NPK contributed more weight of curd $(529.68 \mathrm{~g})$ followed by $\mathrm{T}_{5}(100+60+50) \mathrm{kg} / \mathrm{ha}$ NPK giving $415.04 \mathrm{~g}$ curd weight/plant. Minimum weight was recorded with $\mathrm{T}_{1}$ (No NPK).
The data presented in table 7 indicate that mixture of NPK fertilizers $\mathrm{T}_{6}(120+80+60)$ $\mathrm{kg} / \mathrm{h}$ NPK gave significantly higher yield (206.57 q/ha), followed by mixture of fertilizers $\mathrm{T}_{5} \quad(100+60+50) \quad \mathrm{kg} / \mathrm{ha} \quad \mathrm{NPK}$ observed (168.12 q/ha) and minimum in found $\mathrm{T}_{1}$ (Control) (99.75 q/ha). These views are also reported by many scientists like Everaarts and DE Willigen (1999), Ahmed et al., (2003). Randhawa and Bhail (1976) and Cutecliffe and Munro (1976). Rajput and Singh (1975) reported the best results in response to $80 \mathrm{~kg} / \mathrm{ha}$ as a basal dose followed by top dressing. 
Findings of the scientists Tripathi (2012), Kodithuwakku and Kirthisinghe (2009), Pawar and Barkule (2017) also support the present result.

\section{References}

Ahmed, S; Ahmed, F.; Faridullah and Hussain, M. (2003). Effect of different NPK levels on the growth and yield of kohlrabi (Brassica caulorapa L.) at Northern areas of Pakistan. Asian J. Plant Sci. 2(3): 336-338.

Everaarts, A.P., and P. DE Willigen (1999). The effect of nitrogen and the method of application on yield and quality of broccoli Netherlands J. of Agri. Sci. 47-123-133.

Kodithuwakku, D.P. and J.P. Kirthisinghe (2009). The Effect of Different Rates of Nitrogen Fertilizer Application on the Growth, Yield and Postharvest Life of Cauliflower (Brassica oleracea var. botrytis L.). Tropical Agri. Res., 21(1): 110-114.

Pawar R. and Barkule S. (2017). Study on effect of integrated nutrient management on growth and yield of cauliflower (Brassica oleracea var. botrytis L.). J. of App. and Natural Sci., 9(1): 520-525.

Rajput, C.B. and Singh, K. P. (1975). Response of cauliflower cultivar, "snowball-16" to various levels, methods on nitrogen application. Bangia Desh Hort., 3(7): 23-30.

Randhawa, K.S. and Bhail, A.S. (1976). Grow the yield and quality of cauliflower, (Brassica oleracea var. botrytis L.) as influenced by nitrogen, phosphorus and boron. Indian J. Hort., 83.

\section{How to cite this article:}

Gangesh Pandey, K. K. Mishra, Aneeta Yadav and Abhishek Tiwari. 2019. Effect of the Best Dose of N, P and K Fertilizers for Better Growth and Yield of Cauliflower (Brasica oleracea Var. botrytiss L.). Int.J.Curr.Microbiol.App.Sci. 8(10): 2153-2163. doi: https://doi.org/10.20546/ijcmas.2019.810.251 